\title{
Curriculum Design and Teacher Educators' Digital Competence: Promoting Learner-Centered Teaching Approach in Higher Institutions of Learning
}

\author{
David Kakeeto $^{1}$, Anthony Muwagga Mugagga ${ }^{2}$, Ronald Bisaso ${ }^{3}$ \\ ${ }^{1}$ Lecturer, Department of Computing and Information Science, Nkumba University. Kampala Uganda \\ ${ }^{2}$ Senior Lecturer, School of Education, College of Education and External Studies, Makerere University. \\ Kampala Uganda \\ ${ }^{3}$ Dean, The East African School of Higher Education Studies and Developm ent (EASHESD), College \\ of Education and External Studies, Makerere University. Kampala Uganda \\ Email: dkakeeto@gmail.com
}

\begin{abstract}
The study was set out to establish how curriculum design influences teacher educators' digital competence at Makerere University. It was hypothesized that, curriculum design influences teacher-educators' digital competence. A case study design was employed taking a quantitative approach. Participants were teacher trainers from School of Education and data were collected using a self-administered questionnaire. Data were analyzed using Pearson Product moment Correlation coefficient. Results indicated that, curriculum design and development has got a significant positive influence to teacher educators' technology knowledge and skills. It was concluded that; any curriculum that does not include technology knowledge and skills is not aimed at addressing the needs of the 21st century learners, whom we refer to as digital natives and therefore all institutions must take ICT integration as a fundamental component of today's teaching and learning. And it was recommended that; The School of Education should develop an evaluative instrument to regularly assess the extent to teacher trainers in all departments implement technology knowledge and skills in teaching and learning process.
\end{abstract}

Keywords: curriculum; design; technology; skills and knowledge

\section{Introduction}

Since time inertia, ICT has been looked at as multipurpose tool which has greatly improved and simplified human life and activity. Higher education institutions around the world today have increasingly adopted ICT as a tool for teaching, curriculum development, staff development and student learning (Usluel, Askar, \& Bas, 2008). The reforms in curricula and in pedagogical practices have broadened in scope and magnitude in recent decades by integrating social dimension into the teaching. Pedagogical innovations have been explored using information and communication technology and these reforms have been also driven by theories of progressivism and human learning and development such as; social constructivism (Martinez-Garcia et al., 2012). Teaching through ICT helps students to understand the study content, since ICT makes learning a reality, practical and real existence. It is believed that, students retain $20 \%$ of what they hear, $40 \%$ of what they see and hear and $75 \%$ of what they see and do (Aktaruzzaman, Shamim \& Clement, 2011). For this reason, most of the teacher educators around the world are trying to engage their learners in a lively knowledge building process which requires an understanding of pedagogical principles which involve the use of ICT in instructional settings, learning must be active where we encourage learners to actively participate in the knowledge construction process. 
Despite the effort put into promoting ICT integration in teaching at Makerere University, teacher educators' digital competence levels in form of technology knowledge and skills have remained very low and teaching has remained traditional (Lubega, Kajura and Muyinda, 2014). Muyinda (2013) had actually attributed this to high preference for teachercentered paradigms, which is an aspect to be addressed in curriculum design and development. Therefore, the study explored the extent to which curriculum design influence teacher educators' digital competence in form of technology knowledge and skills at Makerere University.

\subsection{Aim}

Establish how curriculum design influences teacher educators' digital competence at Makerere University, School of Education.

\section{Review of Literatures}

\subsection{Curriculum Design and Technology Knowledge and Skills}

Reforms in curricula and in pedagogical practices have broadened in scope and magnitude in recent decades by integrating information and communication technology in teaching, hence the need for digital knowledge and skills. Kirsti (2011) defines knowledge as information in the mind, ability to understand something, possess some information whereas skills refer to the practical proficiency, potential or ability to perform something in a practical sense. Teachers around the world today are taking a skills-based approach to education to prepare students to build careers and be active citizens after completing school (Sahlberg, 2010).

Preparing teachers today to meet future challenges is a major mission of higher education in Uganda, so that the children are brought up as knowledge creators not merely consumers. Faculties, departments or colleges have considerable autonomy over curriculum issues and the process of teaching and learning (Bergquist \& Pawlak, 2008). So, the way a curriculum is designed and developed must clearly indicate the pedagogical aspects of ICT integration.

Tosun \& Barişusing (2011:223) believed that universities which want to reposition themselves in the market, they must have a strategic plan which clearly indicates how technology integration should be done. Researchers like Shuva (2010) revealed that, educational systems around the globe are all becoming increasingly pressured to apply the new ICT tools to their curriculum to provide students with technology knowledge needed in the 21 st century. In today's world of employment, technology knowledge has become very pertinent and almost compulsory especially in teaching, due to the fact that, we are dealing with digital natives who can hardly study in a traditional style.

Plowman et al. (2010) found out that, almost all children aged three and four are growing up in homes which have a range of different technologies. They found that $98 \%$ of their survey respondents' children were living in a household with access to a mobile phone and $75 \%$ had access to a television with interactive features (p. 308). Their study further indicated that, most of the children surveyed also had access to laptops, games consoles, handled games, laptops and interactive books (p.308). 
Although on the other hand, Laurillard (2013) informs us that, even if teachers and students use technology, this does not necessarily mean that they can teach or learn with it. Because using technology to learn does not come naturally to everyone, digital skills should not be treated as independent of context (Young, 2012), but both teachers and students should be exposed to technology skills applicable across the curriculum (Collin \& Karsenti, 2013). Even, Koehler \& Mishra (2009) revealed that, the application of technology skills in teaching and learning is not context free; yet professional development centered on isolated technology skills has been prevalent in most institutions especially in developing countries. This calls for thorough review of curriculum to ensure that technology integration is part of syllabus, this approach helps both teachers and learners to know how and where to use ICTs. Ling (2014) reveals that, among the Educational reforms today involve is pedagogical innovations which involve ICT integration so as to reduce teacher-dominated pedagogy and also to minimize examination-oriented knowledge transmission which does not cultivate students' critical thinking and problem solving skills, so today's curriculum requires ICT integration.

\section{a. Study Hypothesis}

$\mathbf{H}_{1}$ : Curriculum design influences teacher-educators' digital competence.

\section{Research Methods}

\subsection{Research Design}

The research adopted a case study design applying a quantitative approach, and a correlation design involving use of a Likert scaled Self administered questionnaire.

\subsection{Participants}

The researcher targeted teacher trainers in the School of Education, College of Education and External studies, Makerere University and 26 participants were selected from three departments: Humanities and Language Education, Science, Technical and Vocational Education plus the Foundation and Curriculum Studies, stratified and simple random sampling techniques were applied.

\subsection{Data Collection Instruments}

Being a quantitative, a self administered questionnaire was used to collect data from the participants. The questionnaire basically had four sections; background variables, the dependent (digital competence) and the independent variables (curriculum design).

\subsection{Data Analysis}

Data were subjected to a quantitative analysis at both univariate and bivariate levels. At univariate level, descriptive statistics were used while at the bivariate level; the study applied Pearson's product Moment Correlation.

\section{Results and Discussion}

\subsection{Results}

\section{a. Description of the Independent Variable Curriculum Design}

The independent variable was curriculum design which covered the design, development and delivery. To obtain data on the above statement, the researcher had a list of test items which addressed different areas of concern from which the respondents self rated their perceptions. Self-rating was based on Likert scale ranging from one which represents 
strongly disagree and five to mean strongly agree. Descriptive statistics on respondents' selfrating of curriculum design Table 1 :

Table 1. Descriptive Statistics on Curriculum Design and Development

\begin{tabular}{|l|r|r|r|r|r|}
\hline & N & Min. & Max. & $\begin{array}{r}\text { Me } \\
\text { an }\end{array}$ & $\begin{array}{c}\text { Std. } \\
\text { Dev. }\end{array}$ \\
\hline $\begin{array}{l}\text { The way the curriculum is designed requires } \\
\text { application of digital skills and knowledge }\end{array}$ & 26 & 4.00 & 5.00 & $\begin{array}{r}4.15 \\
38\end{array}$ & .36795 \\
\hline $\begin{array}{l}\text { Curriculum content preparation today calls digital } \\
\text { skills and knowledge }\end{array}$ & 26 & 4.00 & 5.00 & $\begin{array}{r}4.15 \\
38\end{array}$ & .36795 \\
\hline $\begin{array}{l}\text { Content delivery necessitates the application of } \\
\text { digital skills and knowledge }\end{array}$ & 26 & 2.00 & 5.00 & $\begin{array}{r}3.61 \\
54\end{array}$ & .99305 \\
\hline $\begin{array}{l}\text { Modern learner assessment of the calls for the use } \\
\text { of digital skills and knowledge }\end{array}$ & 26 & 2.00 & 5.00 & $\begin{array}{r}3.71 \\
54\end{array}$ & .89786 \\
\hline $\begin{array}{l}\text { Learner feedback requires some use of digital skills } \\
\text { and knowledge }\end{array}$ & 26 & 4.00 & 5.00 & $\begin{array}{r}4.15 \\
38\end{array}$ & .36795 \\
\hline $\begin{array}{l}\text { Collaborative activities in the curriculum require } \\
\text { the use of digital skills and knowledge }\end{array}$ & 26 & 2.00 & 5.00 & $\begin{array}{r}3.88 \\
46\end{array}$ & .71144 \\
\hline $\begin{array}{l}\text { Action project work in the curriculum requires } \\
\text { application of digital skills and knowledge }\end{array}$ & 26 & 2.00 & 5.00 & $\begin{array}{r}3.11 \\
54\end{array}$ & .99305 \\
\hline
\end{tabular}

\section{Source: Primary data, 2019}

The independent variable studied was curriculum design which basically concentrated on the way the curriculum is designed, developed and delivered. Study results have indicated that: the process of curriculum designed requires application of digital skills and knowledge (mean $=4.15)$; curriculum content preparation also calls for the use of digital skills and knowledge (mean $=4.15)$; delivery of content to students necessitates the application of digital skills and knowledge (mean $=3.61)$; modern learner assessment of the calls for the use of digital skills and knowledge (mean $=3.71)$; learner feedback requires some use of digital skills and knowledge $($ mean $=4.15)$; collaborative activities in the curriculum require the use of digital skills and knowledge $($ mean $=3.88)$; however, participants did not reveal whether action project work in the curriculum requires application of digital skills and knowledge (mean = 3.11) and this could be attributed to perhaps limited action project work in the current curriculum. Thereafter, all the test items for this variable were aggregated into a single index (CurDes) standing for curriculum design.

\section{b. Description of the Dependent Variable: Digital Competence}

This Section gives a description of the dependent variable (Digital competence) which was looked at as; technology knowledge and skills were conceptualized using ten test items which required each respondent to do self-rating on digital competence levels and the results were as indicated below:

Table 2. Descriptive Statistics on Teacher Educators' Digital Competence

\begin{tabular}{|l|r|r|r|r|r|}
\hline Test items & N & Min. & Max. & Mean & $\begin{array}{c}\text { Std. } \\
\text { Dev. }\end{array}$ \\
\hline $\begin{array}{l}\text { ICT in education has changed the way } \\
\text { I work in my classroom through } \\
\text { improved communication }\end{array}$ & 26 & 1.00 & 5.00 & 3.5000 & 1.67929 \\
\hline
\end{tabular}




\begin{tabular}{|l|r|r|r|r|r|}
\hline $\begin{array}{l}\text { Using ICT in education has facilitated } \\
\text { my teaching through content creation. }\end{array}$ & 26 & 1.00 & 5.00 & 3.6538 & 1.32491 \\
\hline $\begin{array}{l}\text { ICT in education has contributed to } \\
\text { cooperation between me and my } \\
\text { students in terms information sharing. }\end{array}$ & 26 & 1.00 & 5.00 & 4.0000 & 1.20000 \\
\hline $\begin{array}{l}\text { Using ICT teaching has made students } \\
\text { more active and promotes problem- } \\
\text { based learning }\end{array}$ & 26 & 1.00 & 5.00 & 3.2692 & 1.34336 \\
\hline $\begin{array}{l}\text { Using ICT in teaching has increased } \\
\text { students' awareness in a range of } \\
\text { themes and promotes creativity. }\end{array}$ & 26 & 1.00 & 5.00 & 3.5769 & 1.23849 \\
\hline $\begin{array}{l}\text { ICT in education makes teaching and } \\
\text { learning funnier because of the } \\
\text { continued collaborations amongst } \\
\text { teachers and students }\end{array}$ & 26 & 3.00 & 5.00 & 4.4231 & .70274 \\
\hline $\begin{array}{l}\text { ICT in education prepares students for } \\
\text { their future career in the digital era. }\end{array}$ & 26 & 2.00 & 5.00 & 4.4615 & .70602 \\
\hline $\begin{array}{l}\text { ICT in education is important in order } \\
\text { to prepare students to be active } \\
\text { members of the public }\end{array}$ & 26 & 2.00 & 5.00 & 3.8846 & 1.03255 \\
\hline $\begin{array}{l}\text { ICT in education develops teachers' } \\
\text { pedagogical ability from teacher } \\
\text { centered to learner centered approach. }\end{array}$ & 26 & 1.00 & 5.00 & 4.3846 & .85215 \\
\hline $\begin{array}{l}\text { Teacher trainers should have ICT } \\
\text { knowledge and skills in order to } \\
\text { support learners' ability to construct } \\
\text { knowledge. }\end{array}$ & 26 & 4.00 & 5.00 & 4.8846 & .32581 \\
\hline
\end{tabular}

\section{Source: Primary data, 2019}

The dependent variable (Digital competence) was looked at in form of technology knowledge and skills, respondents agreed to the following responses as indicated by the mean values: ICT in education has changed the way I work in my classroom through improved communication, mean value $=3.50$. This shows that, many teacher educators have at least used ICT to some extent to support their teaching especially in creating content as also indicated in following statement; Using ICT in education has facilitated my teaching through content creation, mean $=3.65$; ICT in education has contributed to cooperation between me and my students in terms information sharing, mean $=4.00$. There is no doubt that use of ICT in teaching promotes learner collaboration; Using ICT in teaching has increased students' awareness in a range of themes and promotes creativity, mean $=3.57$; ICT in education makes teaching and learning funnier because of the continued collaborations amongst teachers and students, mean $=4.42$; ICT in education prepares students for their future career in the digital era, mean $=4.46$; ICT in education is important in order to prepare students to be active members of the public, mean $=3.88$; ICT in education develops teachers' pedagogical ability from teacher centered to learner centered approach, mean $=4.38$; Teacher trainers should 
have ICT knowledge and skills in order to support learners' ability to construct knowledge, mean score $=4.88$. All the above responses do indicate that technology knowledge and skills are fundamental in promoting technology integration in teacher training. There was only one test item, "Using ICT teaching has made students more active and promotes problem-based learning" which received mean value $=3.26$, indicating that the participants were not so sure whether the student teachers were more active and had the ability solve problem-based learning. May be learners have not fully exhibited their technology skills and knowledge since many of their tutors have also failed up to explore these technologies to support their teaching. For purposes of finding out whether curriculum design (CurDes) influences teacher educators' digital competence, all the test items on dependent variable i.e., digital competence were aggregated in one index and named it, "DigComp" which is an acronym for digital competence.

\section{c. Verification of the Hypothesis}

The hypothesis was stated that, $\mathbf{H}_{1}$ : "curriculum design influences teacher-educators' digital competence at Makerere University".

Table 3. Pearson's Correlation Co-efficient for Curriculum Design and Teacher Educators' Digital Competence

\begin{tabular}{|l|l|r|r|}
\hline \multicolumn{2}{|l|}{ Correlations } & \multicolumn{1}{|c|}{$\begin{array}{c}\text { Curriculum } \\
\text { Design } \\
\text { (CurDes) }\end{array}$} & \multicolumn{1}{|c|}{$\begin{array}{c}\text { Digital Competence } \\
\text { (DigComp) }\end{array}$} \\
\hline \multirow{5}{*}{ Curriculum Design } & $\begin{array}{l}\text { Pearson } \\
\text { Correlation }\end{array}$ & 1 & $.552^{* *}$ \\
\cline { 2 - 4 } & Sig. (2-tailed) & 26 & .003 \\
\cline { 2 - 4 } & $\mathrm{N}$ & $.552^{* *}$ & 26 \\
\hline \multirow{5}{*}{ Digital Competence } & $\begin{array}{l}\text { Pearson } \\
\text { Correlation }\end{array}$ & .003 & 26 \\
\cline { 2 - 5 } & Sig. (2-tailed) & 26 & \\
\cline { 2 - 5 } & $\mathrm{N}$ & & \\
\hline \multirow{2}{*}{$* *$ Correlation is significant at the 0.01 level (2-tailed). }
\end{tabular}

Table 3: shows that, Pearson's Correlation Coefficient for curriculum design(CurDes) and digital competence (DigComp), was $\mathbf{r}=\mathbf{0 . 5 5 2}$, which was positive with probability value ( $\mathrm{p}=\mathbf{0 . 0 0 3}$ ) less than $\boldsymbol{\alpha}=\mathbf{0 . 0 1}$ suggesting a significant correlation, implying that curriculum design significantly positively correlated with teacher educators' digital competence at Makerere University at the one percent level of significance. This implies that, way the curriculum is designed will determine whether the teacher educator will apply technology skills and knowledge, a well designed curriculum includes components of technology applications especially the way the content is delivered, assessed and feedback aspects.

\subsection{Discussion}

The study findings indicated that, curriculum design and teacher educators' digital competence in terms of knowledge and skills are significantly positively related. The way the curriculum is designed will determine whether the teacher educator will apply technology skills and knowledge. Teachers around the world today are taking a skills-based approach to education to prepare students to build careers and be active citizens after completing school (Sahlberg, 2010). Thus, it is important to minimize any gap between technology knowledge and skills required by teachers in the future. Along the same line, Tosun \& Barişusing (2011:223) indicated that universities which want to reposition themselves in the market, they must have a strategic plan which clearly indicates how technology integration should 
be done, and this arrangement must be in line with the teaching curriculum. Again, Aguti (2016) found out that to promote teacher educators' digital skills and knowledge, there is still need for continuous transformation of the curriculum to include ICTs for teaching and learning process. Obunadike, (2009) warns teacher educators that, if teachers are to make their instruction more career relevant and practical for their students, they need to know which essential digital knowledge and skills which will be transferable across different fields of work in the 21 st century. This digital competence concept is over emphasized because, it helps students to become knowledge developers other than consumers, promotes learner-centered approach and since knowledge creation is an interaction process between student, teacher and content, ICT provides a flexible learning environment.

\section{Conclusion}

Any curriculum that does not include technology knowledge and skills is not aimed at addressing the needs of the $21^{\text {st }}$ century learners, whom we refer to as digital natives and therefore all institutions must take ICT integration as a fundamental component of today's teaching and learning.

\section{References}

Bergquist, W. \& Pawlak, K. (2008). Engaging the Six Cultures of the Academy. San Francisco: Jossey-Bass.

Collin, S., \& Karsenti, T. (2013). Usages des technologies en éducation : Analyse des enjeux socioculturels. Éducation et francophonie, 41(1), 192-210.

Koehler, M. J., \& Mishra, P. (2009). What is technological pedagogical content knowledge? Contemporary Issues in Technology and Teacher Education, 9(1), 60-70.

Ling Li (2014). Towards a cultural framework to understand teachers' ICT adoption: a case study. Educate Vol. 14, No. 2, 2014, p. 29 43. (http://www.educatejournal.org).

Lubega T. Jude, Mugisha Annet Kajura, and Muyinda Paul Birevu (2014) Adoption of the SAMR Model to Asses ICT Pedagogical Adoption: A Case of Makerere University. International Journal of e-Education, e-Business, e-Management and e-Learning, Vol. 4, No. 2, April 2014

Muyinda B.Paul (2013). "Propelling an ICT-Led Pedagogy at Makerere University". Department of Open and Distance Learning, College of Education and External Studies, Makerere University.

Plowman, Lydia., Joanna McPake and Christine Stephen. 2010. "The Technologisation of Childhood? Young Children and Technology in the Home.” Children \& Society. 24(1):63-74.

Sahlberg, P., \& Boce, E. (2010). Are teachers teaching for a knowledge society? Teachers and Teaching: Theory and Practice, 16(1), 31-48.

Tosun, N. \& Barişusing, M.F., (2011:223), "Information and communications technologies in school improvement", The Turkish online Journal of Education Technology $10(1), 223-230$. 